Influencing and Promoting Global Peace and Security

PHorvon migights Quarterly Journal by Beyond the Horizon ISSG - Volume 3 Issue 4

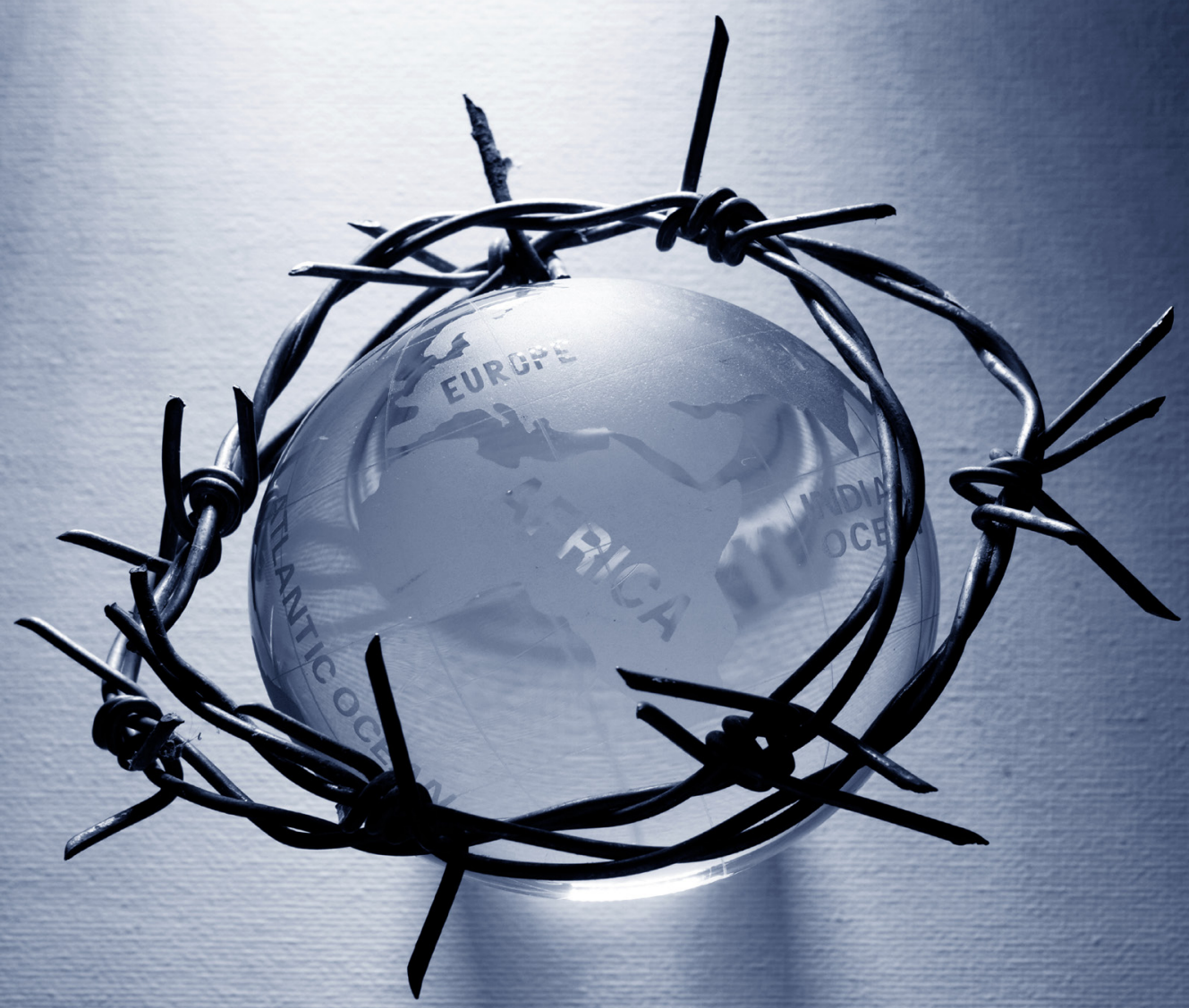

Time to Focus on Building European Security Resilience: Move from Deterring Russian Aggression to Overcoming the Core Problems

NATO-Turkey Relations in a Turbulent Enviroment: The Military Dimension of NATOTurkey Relations
Between Rock and a Hard Place French Vision of Radicalisation and an Alternative Perspective

Book Review: The New Despotism 
Beyond the Horizon International Strategic Studies Group (ISSG) is a non-partisan, independent, and non-profit think tank organisation. The mission of Beyond the Horizon is to influence and promote global peace and security by empowering decision and policy makers and advocating paths to build a better world and prevent, mitigate or end crisis and conflict.

Beyond the Horizon is determined to be a unique think tank with a focus on realistic policies and in-depth analyses to offer comprehensive solutions on topics related to international politics and security, peace and conflict studies.

\section{Disclaimer and Other Legal Information}

The views and opinions expressed in this journal are those of the authors and do not necessarily reflect the official policy or position of any other agency, organisation, employer or company. Assumptions made in the analyses are not reflective of the position of any entity other than the author(s) - and, since we are critically-thinking human beings, these views are always subject to change, revision, and rethinking at any time.

The authors and the journal are not to be held responsible for misuse, reuse, recycled and cited and/or uncited copies of the content by others.

\section{Editorial Board}

Prof. Christopher Coker, London School of Economics and Political Science, London, England.

Prof. Hall Gardner, The American University of Paris, Paris, France.

Prof. Žiga Turk, The University of Ljubljana, Ljubljana, Slovenia.

Prof. Michel Liegeois, Université catholique de Louvain, Leuven, Belgium.

Prof. Felipe Pathé Duarte, The Higher Institute of Police Sciences and Internal Security, Lisbon, Portugal.

Prof. Tanguy Struye De Swielande, Université catholique de Louvain, Leuven, Belgium.

Prof. Rodrigo Alvarez Valdes, University of Santiago, Santiago, Chile.

Prof. Christian Kaunert, University of South Wales

Assoc.Prof. Anne Speckhard, ICSVE and Georgetown University, USA.

Assoc.Prof. Sarah Perret, LabToP-CRESPPA, Paris, France.

Ass.Prof. Salvin Paul, Sikkim University, Gangtok, India.

Ass.Prof. Gabriel Johnson, Stockholm University, Stockholm, Sweden.

Dr. Robert M. Cutler, Carleton University, Ottawa, Canada.

Dr. Steven Blockmans, CEPS, Brussels, Belgium.

Dr. David Strachan-Morris, University of Leicester, Leicester, England.

Dr. Ardian Shajkovci, ICSVE, USA.

Dr. Julien Theron, Paris Lumières University, Paris, France.

Dr. Syed Hussain Shaheed Soherwordi, University of Peshawar, Peshawar, Pakistan.

Dr. Çlirim Toci, Baltic Defence College, Tartu, Estonia.

Dr. Mohammad Salman, Vrije Universiteit Brussel, Brussel, Belgium.

Giorgi Bianisvili, Georgia External Security Department, Tbilisi, Georgia.

Samantha North, University of Bath, Bath, UK.

Kate Jackson, Integration Consulting Group, Brussels, Belgium.

\section{(C) 2020 Horizon Insights}

Horizon Insights 2020-4 (2020 October - December)

DOI : $\quad 10.31175 /$ hi.2020.04

ISSN: $\quad 2593-3582$ (printed)

ISSN: $\quad$ 2593-3590 (online)

Please cite as: Surname, Name (Writer) (2020), “Article name", Horizon Insights - 2020/4, Brussels. For more information visit www.behorizon.org 


\section{Contents}

Foreword

Time to Focus on Building European Security Resilience:

Move Form Deterring Russian Agression to Overcoming the Core Problems

NATO-Turkey Relations in a Turbulent Enviroment:

The Military Dimension of NATO-Turkey Relations

Between Rock and a Hard Place-French Vision of

Radicalisation and a Alternative Perspective

Book Review: The New Despotism 


\section{Foreword}

\section{Dear Reader,}

We are happy to be with you in this last issue of this year. 2020 was not an easy year and were full of conflicts, wars and challenges, including the COVID-19 pandemic. In this issue, we focused on the individual states, i.e., Russia, Turkey and France, and the developments therein which have global effects.

The first article revisits European Union's sanction regime against Russia, given that the latter has been challenging the former's security with its new concept of legitimate spheres of influence and its implementation in Moldova, Georgia and Ukraine. The article argues that a sanctions regime which includes economic and political sticks together with an engagement and dialogue carrot would perfectly fit for purpose.

The second article, which is a policy brief, examines the military relations between NATO and Turkey to unravel the recent (political) discourses and narratives revolving around Turkey's membership to the Alliance, particularly the removal of Turkey from the Alliance due to its divergent interests and stripping from value-based aspects such as the rule of law and human rights. The policy brief embarks on its analysis through the lens of geography, and geopolitics as such to answer why NATO and Turkey are invaluable for each other while accepting substantial problems and challenges. Then the authors delve deeper into the technicalities of Turkey's membership, enriched with easy-to-read data-driven graphics as well as policy recommendations to both administrations of NATO and Turkey.

The third and the last article provides a socio-economic interpretation of increasing radicalism and terrorist attacks in France. The article does not seek to understand if Islam is in crisis or not as argued by the French President Emmanuel Macron. However, it aims to test the validity of the claims, provide alternative reading to attain a balanced view and make policy recommendations.

In our last issue, we also have a book review on John Keane's book " The New Despotism ». Keane's work comes at such a time that "new despotisms " flourish abundant worldwide as these regimes outperform their predecessors thanks to their ability to learn and adapt.

Last, but not least, Beyond the Horizon ISSG team wishes you a lot of joy and happiness during the holiday season. May the upcoming year bring you health, success and joy. Happy New Year.

Sincerely yours,

Beyond the Horizon ISSG 


\section{Time to Focus on Building European Security Resilience: Move from Deterring Russian Aggression to Overcoming the Core Problems}

Olena Snigyr ${ }^{1}$

Today, in this strange and difficult time of reformatting the global international order, which is already complicated by globalization and a pandemic, the European Union as a community based on the liberal values has no choice but to accept their leadership role as it corresponds to their influence as a global actor. And above all else, due to growing European security reasons.

The united Europe faces a row of systemic challenges - the uneasy process of evolving the EU is combined with a reduction in the US presence in European politics and subsequently finding a balance in the frameworks of Euro-Atlantic relations. The EU-Chinese relations are still a matter of discussion too. The EU's self-awareness and self-determination in the changing world are being conducted under the influence of the purposely destabilized external actors and under Russian pressure to create fast and simple solutions for European security.

The European Union is already a powerful global actor in the economic and technology spheres, and for a period of time has been demonstrating readiness for a more active role in the security dimension of world politics. Under these conditions, European countries should make the correct decisions in the sphere of the European security system to maintain the core of its resilience.

After the Cold War ended, conventional warfare in Europe seemed an anachronism and a senseless "zero sum game", because peaceful coexistence was much more rational and promising. European countries tried to fix the balance of international relations in Europe through the principles of the Helsinki Final Act and the Charter of Paris for a New Europe.

For quite a while, we've been hearing arguments that the comprehensive European security order of 1993-2008 has not been successful (Karaganov, S., Bordachov, T. 2009). That it failed and it is high time for new multilateral dialogues about European security conditions. These arguments are significantly strengthened by the wide-reaching and ongoing Russian hybrid warfare - from conventional weapons to cyber-attacks and disinformation. Since discussions on security reforms are already in place, it is reasonable to look at the realistic goals.

The starting point for undermining the European security system should be defined as the period of the early 1990s, not 2014 or 2008. After the collapse of the Soviet Union and in the atmosphere of the ensuing political chaos, the Russian hybrid operation in Moldova and the Russian army's role in the creation of the Transnistrian enclave (Kolosov, V. 2007) happened almost unnoticed and definitely had not been correctly identified by the European nations. The war in Georgia in 2008 was the Russian incentive and invitation for the Euro-Atlantic community to consider the Russian proposal of a new European security order, which had been announced by President Putin in Munich in 2007 (Putin, V., 2007) and later presented in the form of the Russian-designed European Security Treaty (The Draft of the European Security Treaty, 2009).

Today's international relation system in Europe is truly far from the ideals of the Charter of Paris for a New Europe. The Russian Federation has occupied and tried to annex part of Ukrainian territory and continues its military aggression against Ukraine. At the same time, we hear proposals from the Kremlin, and those who think they understand Russia, about discussing a new "more effective" European security system (Charap, S., Shapiro, J., Dienes, A. \& others, 2019). Under the given circumstances, - when military aggression against Ukraine continues and European countries are being destabilized through all available Russian influence dimensions, - these proposals sound more like an ultimatum than a solution.

The Russian Federation's goal of reformatting the European Security system based on the concept of legitimate spheres of influence is acceptable to the global players who seek the same goals in other

${ }^{1}$ Dr. Olena Snigyr is a non-resident fellow at Beyond the Horizon ISSG. 
parts of the globe. Surprisingly, there are still Russian apologists among Europeans. Those European politicians and experts who support the Russian idea of division lines in Europe believe that peace in their countries will be guaranteed by moving the frontline of the Euro-Atlantic presence away from Russian borders. But for how long? We all remember President Putin`s words, "The Russian borders do not end anywhere" (Putin, V., 2016).

However, in reality, we are talking about moving completely different "division lines." Those that have not been drawn on the geographic map but rather on the map of values, and which gave a feeling of safety for all European countries regardless of their size or military strength. But, there really is a choice. We can accept the failure of the comprehensive European security order based on the Helsinki Final Act and the Charter of Paris for a New Europe and we can agree with the fact that the OSCE and the Council of Europe do not successfully uphold the frameworks of those accords. Then, naturally, the logic of realism with its reliance on the military force will prevail in the European geographical areas. That is what is happening within European security right now. The wants of the stronger materialize in dialogues which advise and limit the foreign policy sovereignty of the weaker. There is a great temptation to exchange values for paper security guarantees. But in the end, there will be neither values nor guarantees.

There is another choice. To understand why the projects aimed at European security has not worked and to try to find ways to fix it. The idea of comprehensive European Security is based on the assumption that the signatory states of the Helsinki Final Act and the Charter of Paris for a New Europe share or at least aspire to common values of democracy, market economy and human rights. It was assumed that relevant principles, enshrined in the given documents, were to become part of the legislature of the signatory countries and thus would guarantee their citizens human rights, democratic governance, and market economy rules. The comprehensive system of European security had been constructed not on forceful restraint, but on trust and the principle of voluntary compliance with those agreements.

To rely on the goodwill and honesty of a partner is always a risk, and international relations are no exception. Still, the examples of NATO and the EU demonstrate that in a value-homogeneous space, the peaceful balance of relations between countries is possible not out of coercion (out of fear of the neighbour's weapons), but through honest partnership and the creation of a network of mutually beneficial interdependence.

The fragility of the European security system in 1993-2008 was caused not only by the fact that Russia did not intend to abide by its commitments, but also due to the limited possibility of political and economic consequences to the violator, which is an inherent fault in the systems of international law. Sanction policies towards Russia today are a purely political decision of some countries, which can be changed tomorrow, even if Russia does not change its policy. In a way, the Council of Europe changed its own regulations simply to return Russia to the meeting room (Vlasenko, V. 2019)

In the European security system, without sanctions, the violator is more likely to use brute force as a means to achieve its goals. The Russian Federation would be completely satisfied with this state of affairs. But would other European countries want that?

Arguably, most European countries, whether members of NATO or the EU, prefer to maintain the unique nature of the European security environment, which allows all its members, both large and small, to feel safe. Internal unity to European associations and their resilience is guaranteed by liberal values, and those values are the objects of systemic aggression by the Russian Federation.

The Russian Federation attacks not only the rule based European order itself, but the Kremlin seeks to destroy what underlies this order - the values. Moscow urges European countries to agree that Europe will be a safer place if interstate relations are based on principles of international relations other than those set by liberal values. That the division into zones of influence will bring stability and greater understanding.

However, the introduction of authoritarian practices in European international relations is unlikely to 
promote peace. Even if these practices are well disguised by democratic rituals.

The inherent features of democratic societies are what makes them vulnerable. In particular, freedom of thought and a culture of dialogue make liberal democracies sensitive to external influences. The ideas and arguments which accept the normalization and legitimization of crime are being discussed during academic and political disputes. At first, they can be rejected by experts and scholars, but without effective measures against influence, "the new political normality" will take roots in political context. And there is the possibility that after some time passes, more European politicians of a new generation can accept the idea of visiting the occupied Crimea and playing along with the dictator's play of pseudo-democracy.

Although, it can be quite the opposite. Europe may appear to be resilient enough to withstand pressure, discern threats, and gain the necessary immunity to the subversive activities of any outside players.

Even in Ukraine, being at the front line of the hybrid war, we feel the lack of knowledge on how to confront multidimensional threats. The effectiveness of our actions is measured by the ratio of trial and error, the price of which is very high for us and the lessons of which we share with our allies towards a common goal. That is why support from united democracies is a literal life-or-death influence for Ukraine. And that is why Ukraine's vital interest is for United Europe to maintain its resilience and become a more powerful security player. Protection of liberal values and a rule-based international order is our common goal.

To fix the shaky European order, it is not necessary to completely destroy it and to create a new matrix of international affairs. It is instead necessary to stick to your own principles and to make the already established rules work. The EU policy of sanctions is a very good example of European States consolidating to protect the European order. And even if sanctions cannot stop some big companies from making money with Russians here and now (which creates the illusion of its inefficiency), we understand that the aim of sanctions' policy is to weaken the authoritarian regime in the future. What should be discussed today is not the lifting of sanctions, as those who "understand Russia" suggest, but the creation of a sanctions mechanism which would sufficiently influence Russia to consider an alternative and more constructive solution to the security problems it has created.

The problem of restoring the legal status of Crimea and the problem of resolving all conflicts created by the Russian Federation - in Ukraine, Georgia and Moldova - have solutions and proven mechanisms within the framework of international law. The interests of the Russian Federation to conduct endless and fruitless negotiations with the purpose of continuing rather than resolving conflicts brings all these problems to a standstill. Obviously, if the Russian Federation does not have the political will to implement the Minsk agreements, then we can offer other peaceful international mechanisms for the de-occupation of the temporarily uncontrolled eastern territories of Ukraine. The issue of de-occupation of Crimea and the maritime areas of Ukraine is a matter of serious discussion by the UN Convention on the Law of the Sea and on security in the Black Sea and Mediterranean regions. And we believe that a small start in resolving the Crimea problem could be a dialogue within the framework of the newly launched Crimean Platform.

Today's security problems in the EU's neighbourhood would not have arisen, and some of them would have never become truly threatening to the whole of Europe if a policy of immediate collective economic and political sanctions against the violator had been pursued alongside a collective policy of engagement and dialogue. In order to become a stronger and safer place, Europe really needs to start getting rid of illusions and using the tools it has. Correcting mistakes and their consequences are more difficult than preventing them. It demands a lot of political will, but it is still possible for all of us. 


\section{Bibliography}

Charap, S., Shapiro, J., Dienes, A., Afontsev, S., Balas, P., Crudu, R., Dobbins, J., Filipchuk, V., Galoyan, D., Kuhn, U., Popov, A., Preiherman, Y., Rieker, P., Silaev, N., Vartanyan, O., Zagorski A. (2019). A Consensus Proposal for a Revised Regional Order in Post-Soviet Europe and Eurasia. RAND Corporation.

Dzhaparova, E., (2020). We are starting the next phase of active advocacy of the Crimean Platform. MFA of Ukraine. 20 October.

Karaganov, S., Bordachov, T. (2009). K novoy arkhitekture evroatlanticheskoy bezopasnosti. [Towards the New Architecture of European Security]. London, 8-9 December.

Kolosov, V. (2007), Rol' 14 Armii v aktivnoy faze Pridnestrovskogo konflikta. [The 14th Army role in the active phase of the Transnistrian Conflict]. Izvestiya VUZov. Severokavkazskiy region. 3, p.39-45.

Proekt Dogovora o Evropeyskoy Bezopasnosti (2009). [Draft of The European Security Treaty]. Moscow, Kremlin.

Putin, V. (2007), Vystupleniye i diskussiya na Munkhenskoy Konferentsii po voprosam politiki besopasnosti. [Speech and discussion at the Munich Conference on Security Policy]. 10 February. Moscow, Kremlin.

Putin, V., Granitsy Rossii ne zakanchivayutsa nigde. [The Russian borders do not end anywhere]. BBC, 24 November.

Vlasenko, V. (2019), Hlava nimetskoji delegatsiyi v PARE: Hjcsz povynna zalyshatysia chlenom Rady Yevropy "z usima pravamy ta oboviazkamy". [The Head of German Delegation to PACE: Russian should stay in PACE with "all rights and duties"]. DW, 10 April. 


\section{NATO-Turkey Relations in a Turbulent Environment: The Military Dimension of NATO-Turkey Relations}

Samet Coban ${ }^{1}$, Furkan Akar $^{2}$

For understanding NATO-Turkey relations: “...You can just look at the map.”

NATO Secretary General Jens Stoltenberg ${ }^{3}$

\section{Background: Changing NATO-Turkey Relations}

Looking at a map is a very traditional but illuminating embarking point upon an analysis regarding NATO-Turkey relationship and its relevance since geography is a constant variable imposing substantial restrictions on devising a strategy and policymaking. In this vein, situated in a location connecting three continents in the Middle East and being the patron of Turkish Straits, and the South-eastern flank of the Alliance, Turkey, has been regarded as an indispensable part of NATO.

Contained by Russia around its borders, exacerbating relations with Armenia, Iran and Syria, Gulf States - despite the recent rapprochement with Saudi Arabia - most of which are exposed to the surging Russian influence, Turkey lives in a very fragile region. Hence, NATO provides a crucial anchor and a security guarantee for Turkey to maintain its stability, security and well-being in its land and around the borders as well in the Middle East. ${ }^{4}$

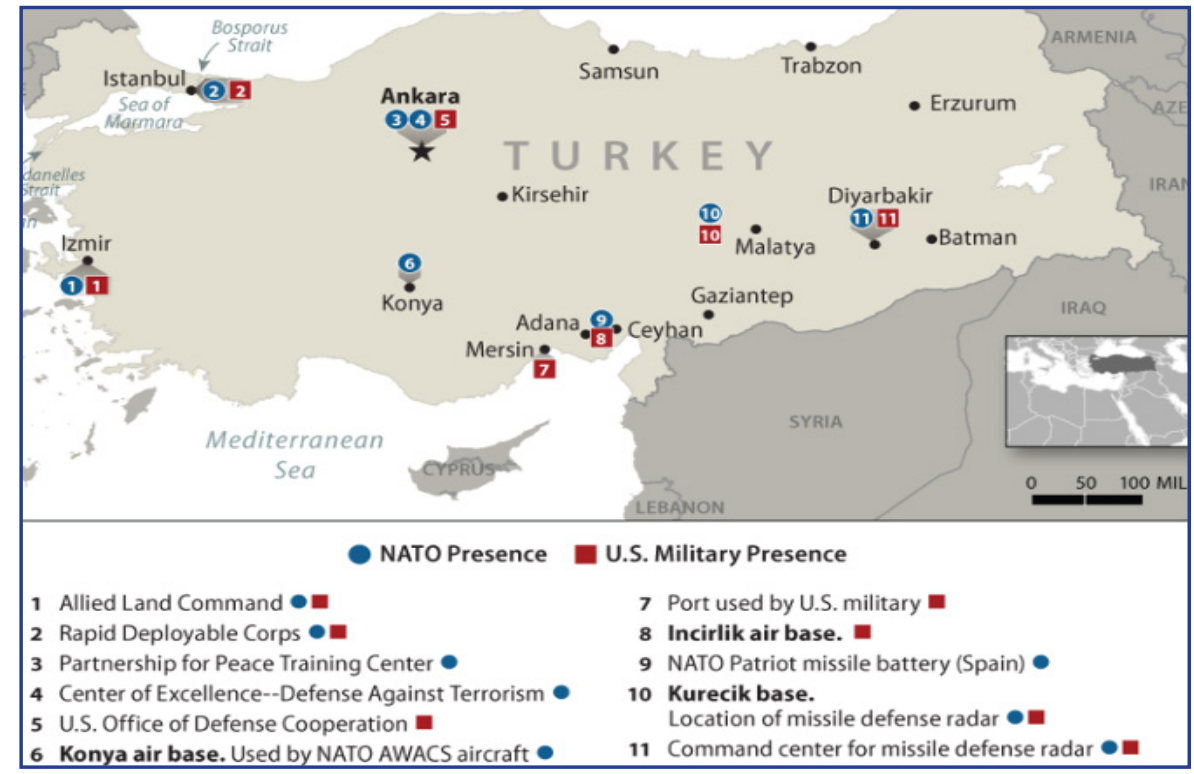

Source: CRS Report Figure A-2, (2020), see footnote 6

On the other side, as James Jeffrey points out "In the Post-Cold War mess...almost all our conflicts you pick one Georgia, Ukraine, Bosnia, Kosovo, Iran nukes, Syria, Gaza. They all involved Turkey, and we could not have done the things we did if Turkey were uncooperative or opposed to it-it's that simple." ${ }^{5}$

\footnotetext{
1 Samet Çoban is a Research Fellow at Beyond the Horizon ISSG.

2 Furkan AKAR is a Research Intern at Beyond the Horizon ISSG.

3 Remarks by President Trump and NATO Secretary General Stoltenberg, London, (2019), https://www.whitehouse.gov/briefings-statements/remarks-president-trump-nato-secretary-general-stoltenberg-11-meeting-london-united-kingdom/

${ }^{4}$ S.Ulgen, Turkey is Learning Why NATO Membership Matters, Bloomberg Opinion, (2020), https://www.bloomberg.com/opinion/articles/2020-03-05/turkey-s-erdogan-is-learning-why-nato-membership-matters

${ }^{5}$ J. Jeffrey, Turkey and the Failed Coup One Year Later, (2017) The Washington Institute, 42:30, https://www.washingtoninstitute.org/policy-analysis/view/turkey-and-the-failed-coup-one-year-later
} 
A Turkey assuming responsibility in the Euro-Atlantic security architecture is of everybody's interest and a win-win situation for both sides. All other options come with hefty prices for both parties.

In recent years, Turkey's increasingly ambitious and assertive policies have differed from its allies, e.g. YPG, S-400, and the Eastern Mediterranean. ${ }^{6}$ The country is backsliding from democracy, experiencing a 'remarkable rapprochement' with Russia ${ }^{7}$ and the current administration is posing a challenge to NATO from within. ${ }^{8}$ Discord between allies is not new, yet the US pullback and domestic dynamics of Turkey exacerbated the intensity and the extent of disputes making it harder to contain them within NATO. ${ }^{9}$

In this context, policy-makers and scholars think whether Turkey comes to a crossroads. Some authors and politicians even contend that the time to expel Turkey from NATO has come, though no mechanism exists as such. ${ }^{10}$ Most analysis in this respect cannot go beyond wishful thinking and cannot answer "so what" question. Before removing any member from the Alliance, it has to be taken into account the technical dimension of the relations, e.g. relocation of NATO/US Assets in Turkey, military (dis)integration with Turkey, and takeover of Turkish Armed Forces' role in the Alliance. Furthermore, if this happens, how to address the disputes with a Turkey outside of NATO is still unclear.

The sui generis power-sharing structure within the Turkish State, even though substantially changed under the current Turkish government, puts Turkish Armed Forces (TAF), arguably the most integrated institution of the Republic with the West, in an exceptional place where it can tip the delicate balance between Turkey and its allies. The literature on the relationship between Turkey and NATO, a politico-military alliance, has surged lately; whereas, the technical/military dimension of it is still understudied. Most of the analysis is heavily based on the consolidated domestic power of the Turkish President and his preferences with respect to Turkish foreign policy, and the Alliance as such. Nevertheless, even if the Turkish President is (or becomes) ambitious about leaving NATO, disintegration and departure from the Alliance are much more challenging than many analysts think.

In this paper, we therefore aim to grasp the factors that make NATO relevant for Turkey, particularly in terms of military dimension. We believe that less is comprehended on the technicalities of Turkey's membership in the context of TAF, that prevents a healthy understanding of NATO's role for Turkey's security and defence, and vice versa.

\section{Political Landscape}

While there are proponents of a harsh response against Turkey and hardliners in Turkey against NATO, not all experts think in the same way ${ }^{11}$, and this is not resonated among all leaders. NATO and Turkish leaders frequently confirmed their commitments publicly. NATO Secretary General reiterated that Turkey is a valued/key ally and "it [Turkey's removal] is not a question". Moreover, most frequent words NATO Chief uses with Turkey are "key ally, valued/valuable ally, and fighting terrorism. ${ }^{22}$ According to

\footnotetext{
${ }^{6}$ J. Zanotti and C.Thomas, “Turkey: Background and U.S. Relations In Brief”, (2020), www.fas.org/sgp/crs/mideast/R44000.pdf

${ }^{7}$ M. Reynolds, Turkey and Russia: A Remarkable Rapprochement, The War on the Rocks (2019), https://warontherocks.com/2019/10/turkey-and-russia-a-remarkable-rapprochement/

8 M. Pierini, How Far Can Turkey Challenge NATO and the EU in 2020?, Carnegie Europe, (2020), https://carnegieeurope.eu/2020/01/29/how-farcan-turkey-challenge-nato-and-eu-in-2020-pub-80912

9 C. Major, 'Catalyst or crisis? COVID-19 and European Security’, October 2020, www.ndc.nato.int/news/news.php?icode=1481

10 J. Babbin, 'Throw Turkey out of NATO', (2019), https://www.washingtontimes.com/news/2019/jul/17/throw-turkey-out-nato; C. Coughlin, 'Erdogan's Gone Too Far. It's Time to Throw Turkey out of NATO', (2019) https://www.telegraph.co.uk/news/2019/07/17/erdogans-gone-far-time-throwturkey-nato/ ; T. Carpenter, 'It's Time to Expel Turkey from the Western Alliance', www.washingtonpost.com/opinions/2019/07/19/its-time-expel-turkey-western-alliance

11 P. Pry, 'Expelling Turkey from NATO Would Create a Dangerous Foe', (2019), www.thehill.com/opinion/international/466747-expelling-turkey-from-nato-would-create-a-dangerous-foe;R. Ellehuus, 'Turkey and NATO: A Relationship Worth Saving', (2019), www.csis.org/analysis/turkey-and-nato-relationship-worth-saving ; J. Stavridis, 'Kicking Turkey Out of NATO Would Be a Gift to Putin', (2019), www.bloomberg.com/opinion/ articles/2019-07-18/kicking-turkey-out-of-nato-would-be-a-gift-to-putin

12 Remarks by NATO Secretary General (2019), www.nato.int/cps/en/natohq/opinions_168351.htm ; Remarks by NATO Secretary General at the joint press conference with the Minister of Foreign Affairs of Turkey, www.nato.int/cps/en/natohq/opinions_178528.htm ; Turkey is a valuable NATO ally. 'Turkey is a valuable NATO ally,'says NATO Chairman'(2020), https://www.nato.int/cps/en/natohq/news_177838.htm; Interview with NATO
} 
Turkish MFA, there seems no change about Turkey's commitments given to NATO. ${ }^{13}$ Turkish Defence Minister stated that "The Alliance enjoys good health. It is not experiencing a brain death." referring to Mr. Macron. Turkish President points out that "The relationships [of] Turkey ... with different countries and regions are not alternatives to each other, they are complementary. Because of the S-400 ... to speculate about our tendency is not to grasp us, our history and geographic location (highlighted). ${ }^{14}$ Even, the Chairman of the Foreign Policy and Defence Council of Russia asserts that "No one in Russia expects Turkey to leave NATO". ${ }^{15}$

\section{From Political Landscape to Military Means}

Unlike political turmoil, military relations between Turkey and NATO are on track. What most analysts agree about is that there is no shrinkage of Turkish military contribution to NATO. Turkey (still) provides substantial contributions to the NATO and EU-led operations. As Flanagan and Wilson point out "engagement slowed somewhat in the immediate months after the coup, almost 95 per cent of planned operations and activities with US Army Europe forces resumed the following year. In fact, the TSK [TAF] participated in ten US Army Europe exercises during 2016, which was a significant increase over previous years." 16

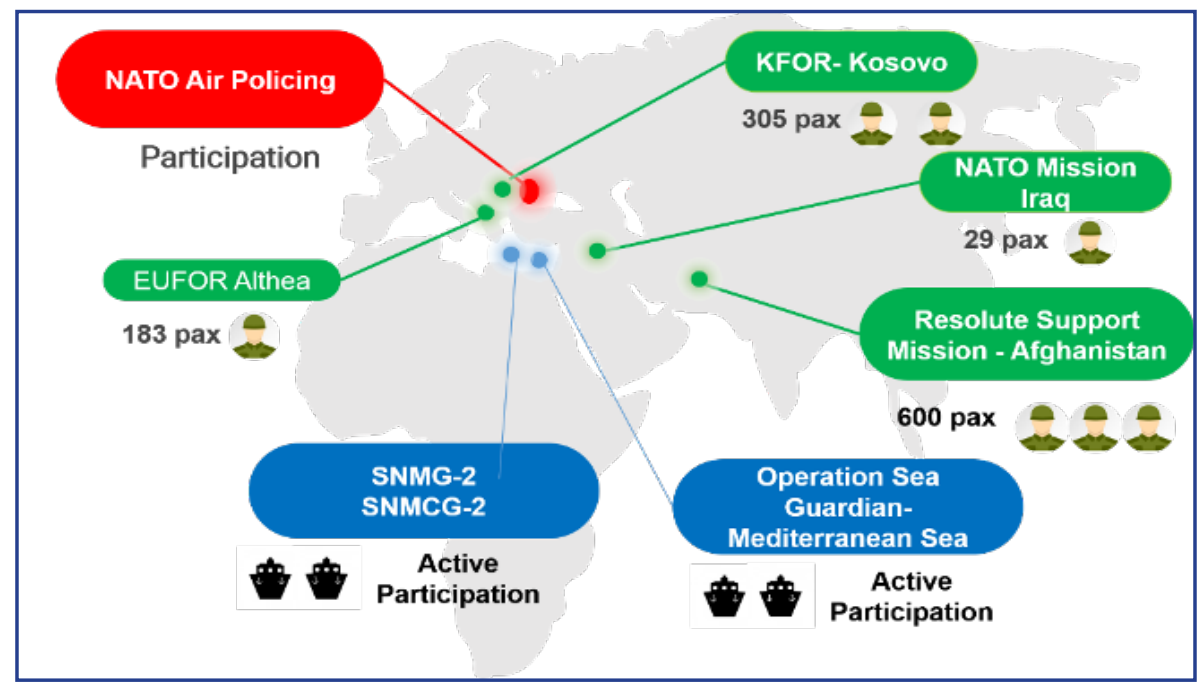

Source: Data compiled from official websites. ${ }^{17}$

Secretary General, NTV, (2019), https://www.ntv.com.tr/video/turkiye/nato-genel-sekreteri-ntvye-konustu-turkiye-natodan-cikarilamaz,vOgQBA-6dEWu3xfE7X7Dog Adapting NATO for 2030 and beyond, Speech by Secretary General (2020), https://www.nato.int/cps/fr/natohq/opinions_179665.htm

13 Turkey's and NATO's views on current issues of the Alliance, Turkish MFA, www.mfa.gov.tr/ii_---turkey_s-contributions-to-international-peace-keeping-activities.en.mfa

14 'S-400 statement from President Erdogan, www.dha.com.tr/politika/cumhurbaskani-erdogandan-s400-aciklamasi/haber-1641054

15 M. Saglam, 'Nobody in Russia expects Turkey to leave NATO', (2020), https://www.gazeteduvar.com.tr/yazarlar/2020/02/26/874600

16 S. J. Flanagan and P. A. Wilson, “Implications for the U.S.-Turkish Partnership and the U.S. Army”, RAND. (2020), https://www.rand.org/pubs/ research_reports/RR2589.html

17 Resolute Support Mission: Key Facts and Figures, www.nato.int/nato_static_fl2014/assets/pdf/2020/6/pdf/2020-06-RSM-Placemat.pdf KFOR Contributing Nations, (2020), www.jfcnaples.nato.int/kfor/about-us/welcome-to-kfor/contributing-nations ; Turkish Troops in Iraq, TAF General Staff, https://www.tsk.tr/Sayfalar?viewName=ContributionToTafToPeace ; For Turkish Assets in the Operation Sea Guardian, see https://mc.nato. int/media-centre/infographics ; Turkey's recent participation to NATO Air Policing, see www.facebook.com/NATO.AIRCOM/posts/on-tuesday-19may-nato-air-policing-jets-from-romania-bulgaria-and-turkey-were-1/3163108817081257/ ; EUFOR Althea uses NATO resources within the scope of Berlin-Plus Agreement, www.shape.nato.int/page39511625.aspx ; This is an overview and not an exhaustive list since all figures are not available in open sources, e.g. Mons, Brussels HQs, and so on. 
Along with these operations, Turkey contributes to the NATO Response Force (NRF) substantially, e.g. hosting an NRDC Headquarters in Istanbul and providing naval vessels to SNMG-2 and SNMCMG-2 that are maritime components of the NRF. More importantly, Turkey will resume the command of NATO's Very High Readiness Joint Task Force (VJTF), the spearhead force of the NRF in 2021 and is expected to assign additional military headquarters regarding NATO Readiness Initiative (NRI). ${ }^{18}$

The active participation of Turkey is incoherent with harsh rhetoric of both sides. In case, a Turkey, which is pivoting to the East, is expected to diminish its contributions. Why doesn't Turkey decouple from NATO at least to some extent? Conversely, cooperation is still increasing amidst tensions. For example, the Maritime Security Centre of Excellence was accredited by NATO in June 2020.19

Turkish Armed Forces is amalgamated with NATO. Its broad participation necessitates a deeper integration, i.e. interoperability and capacity to conduct exercises, campaigns together with the other members of the Alliance. Almost all Turkish assets, whether they are made indigenously or exported, are produced according to NATO standards and contain critical components that are imported from Western allies. Moreover, maintenance and operating procedures, spare parts, technical manuals, field manuals, signals, messaging standards are generated and maintained as such, that requires a specific training and foreign language, i.e. English, know-how, all of which takes a long time to acquire.

NATO countries are Turkey's most critical foreign arms suppliers. Turkey imported/ordered all primary weapons from NATO countries between 2016-2019 except for a training aircraft from Pakistan and S-400 system, that is an extraordinary one with a top-down order as Egeli points out. ${ }^{20}$ For instance, Turkey is the number one customer for the German defence industry, accounting one-third of German arms exports. ${ }^{21}$

Substantial Turkish commitments to NATO entities as well as the active participation of TAF to the NATO missions and operations contradict with the Turkish government's (domestic) political discourse and hardliners in the Western community. This continuation indicates that traditional tendencies are still in place when it comes to defence and security priorities.

\footnotetext{
${ }^{18}$ M. Yetkin, 'Turkey Prepares for More Roles in NATO', (2018), www.atlanticcouncil.org/blogs/natosource/turkey-prepares-for-more-roles-in-nato/

${ }^{19}$ Maritime Security Centre of Excellence, 'Who we are`, (2020), https://www.marseccoe.org/en/who-we-are

${ }^{20}$ For Turkey's arms imports SIPRI Arms Trade, https://armstrade.sipri.org/armstrade/page/values.php ; For Turkey's major arms transfers SIPRI Trade Register; https://armstrade.sipri.org/armstrade/page/trade_register.php ; S.Egeli, 'Making Sense of Turkey’s Air and Missile Defense MerryGo-Round', All Azimuth, 8.1 (2019). https://doi.org/10.20991/allazimuth.470640

21 'More Than One Third of German Military Exports Go To Turkey`, Greek Reporter Europe (2020), www.eu.greekreporter.com/2020/06/23/morethan-one-third-of-german-military-exports-go-to-turkey
} 


\section{Where Does Turkish Armed Forces Stand Among Other NATO Armies?}

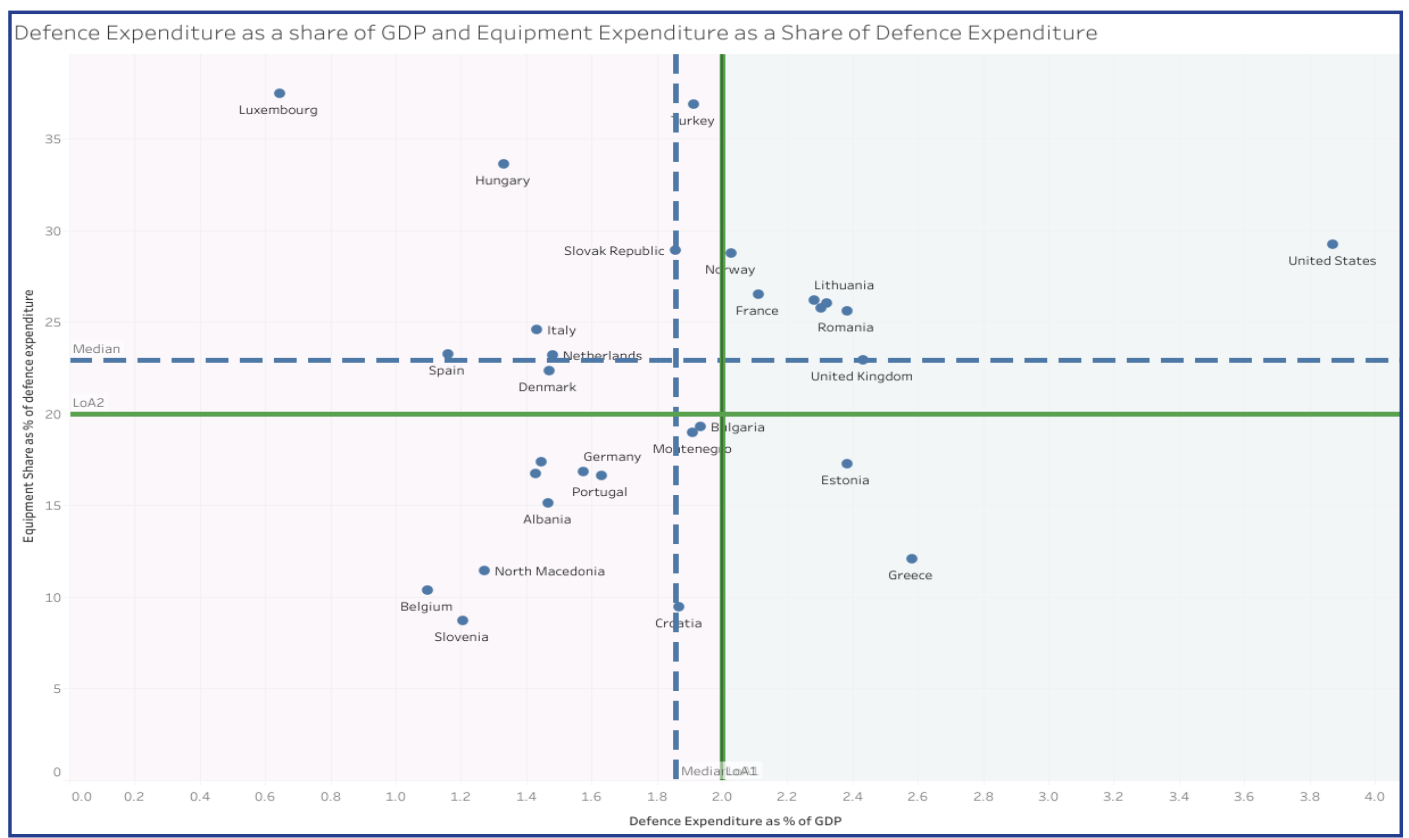

Figure 1. Defence Expenditure as a share of GDP (x) and Equipment Expenditure as a share of Defence Expenditure (y) ${ }^{22}$

The scatter plot shows two NATO defence spending benchmarks, namely, Defence Expenditure share in GDP (a.k.a. the "gold standard" as Trump administration's top national security officials put it ${ }^{23}$ ) and Equipment Expenditure share in Defence Expenditure. 2020 estimates show that Turkey will spend $1.91 \%$ of its GDP (better than half of its NATO Allies) for its defence and $36.9 \%$ of this money will go to equipment (the $2^{\text {nd }}$ best NATO Army, slightly behind Luxembourg).

Using the Defence Expenditure data and military personnel numbers from NATO (2020 estimates) ${ }^{24}$, we created the following graphs to contextualize and understand Turkey's place in NATO.

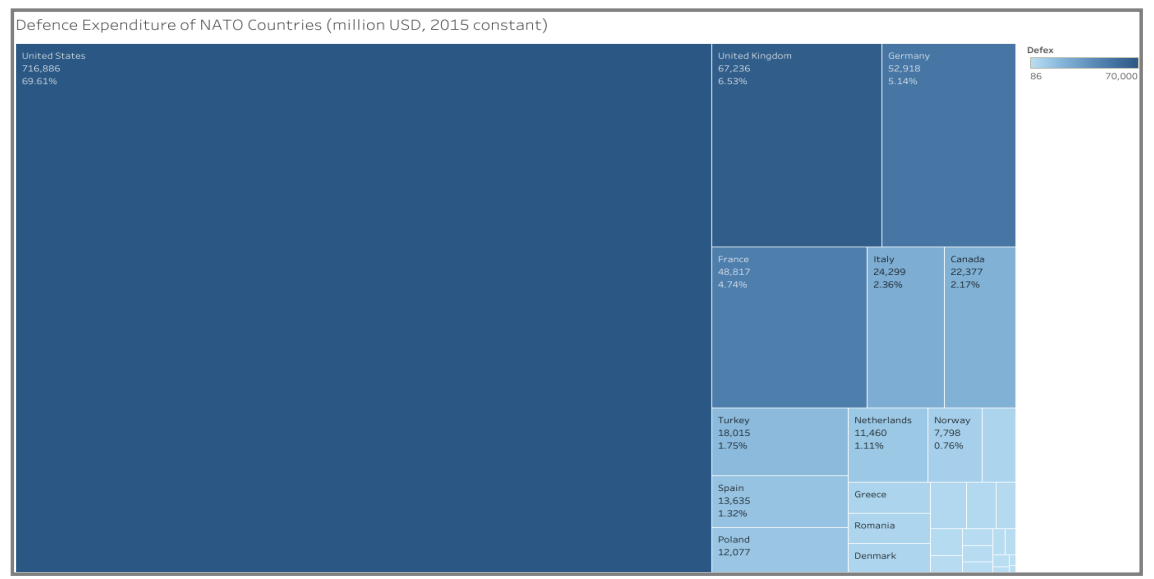

Figure 2. Defence Expenditure Comparison among NATO countries

\footnotetext{
22 PR/CP (2020) 104, Defence Expenditure of NATO Countries (2013-2020), www.nato.int/nato_static_fl2014/assets/pdf/2020/10/pdf/pr-2020-104en.pdf

${ }^{23}$ www.defensenews.com/pentagon/2020/10/21/natos-defense-spending-targets-now-gold-standard-all-allies-should-meet-key-trump-officialssay/

${ }^{24}$ PR/CP (2020)104, Defence Expenditure of NATO Countries (2013-2020)
} 
According to 2020 estimates, Turkey spends roughly USD 18 bn, which is 1.75 per cent of NATO Allies' overall defence spending, that constitutes the $7^{\text {th }}$ defence budget in NATO ( $5^{\text {th }}$ in NATO Europe).

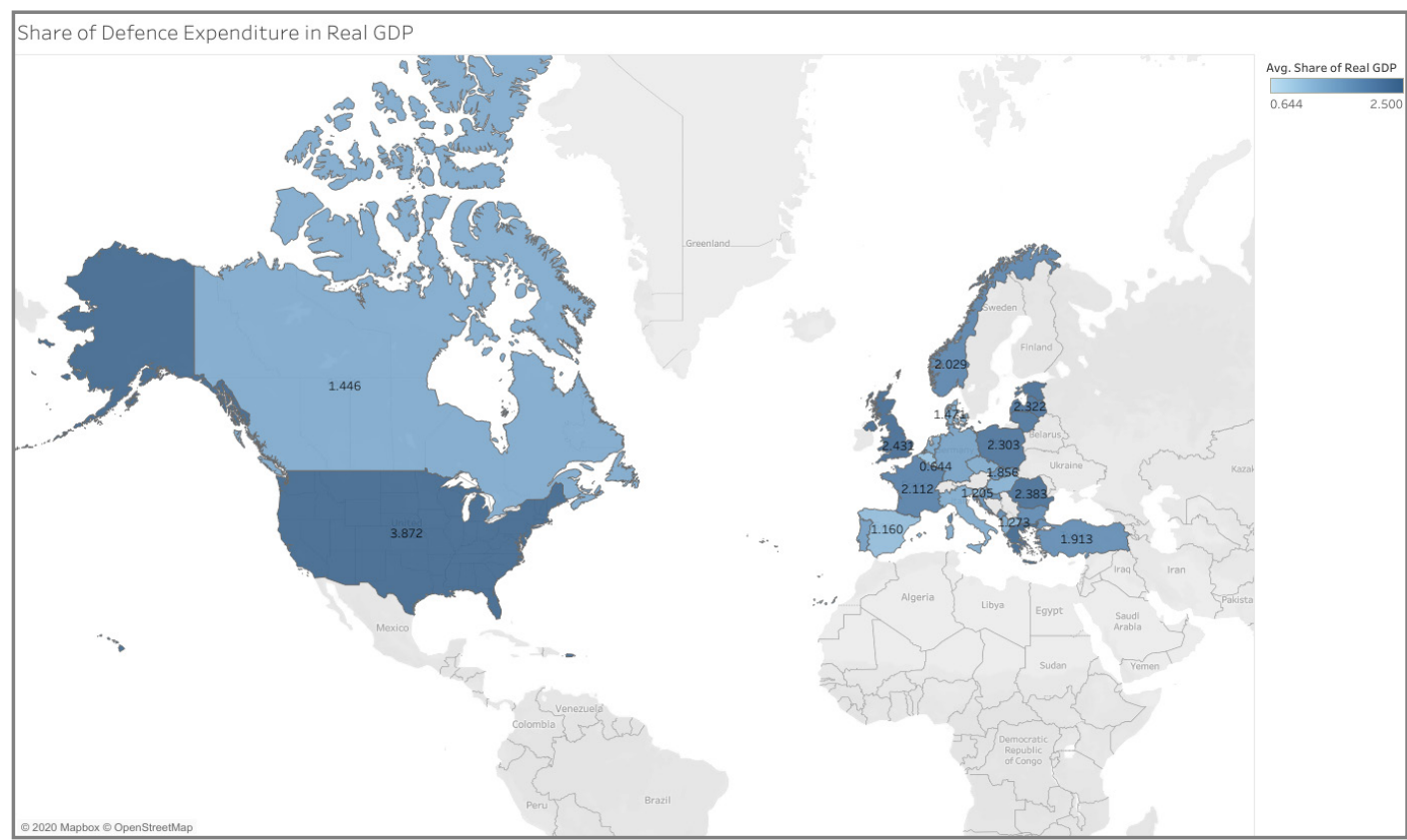

Figure 3. Comparison of NATO Allies‘ defence spending concerning their geography.

Studying defence spending reflexes of countries irrespective of their geography leads to misinterpretations. The map shows that eastern Allies that are close to various "threats," i.e. their proximity spend (proportionally) more on defence. In a NATO without Turkey, the defence burden on the shoulders of the south-eastern flank of the Alliance may increase significantly. On the other hand, defending a Turkey outside of NATO will be very challenging if not impossible.

When we look at the defence expenditure balance between two sides of the Atlantic, money was spent on defence in North America tripled Europe almost throughout the last decade. Kicking out Turkey from the equation will only exacerbate the disparity against continental Europe (presumably in favour of Russia).

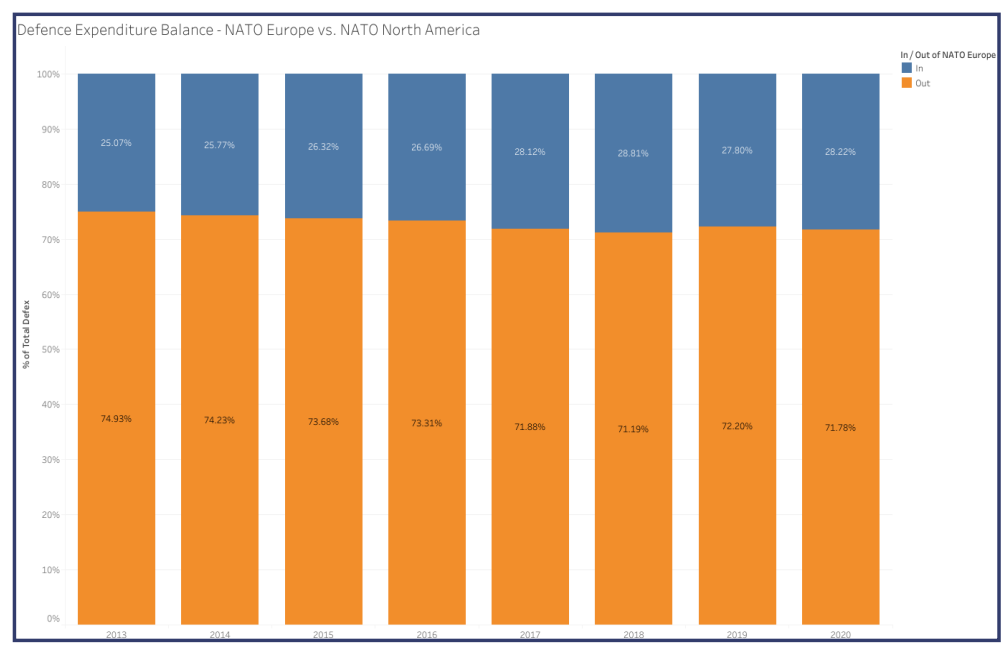

Figure 4. Defence Expenditure Balance- NATO Europe vs NATO North America 


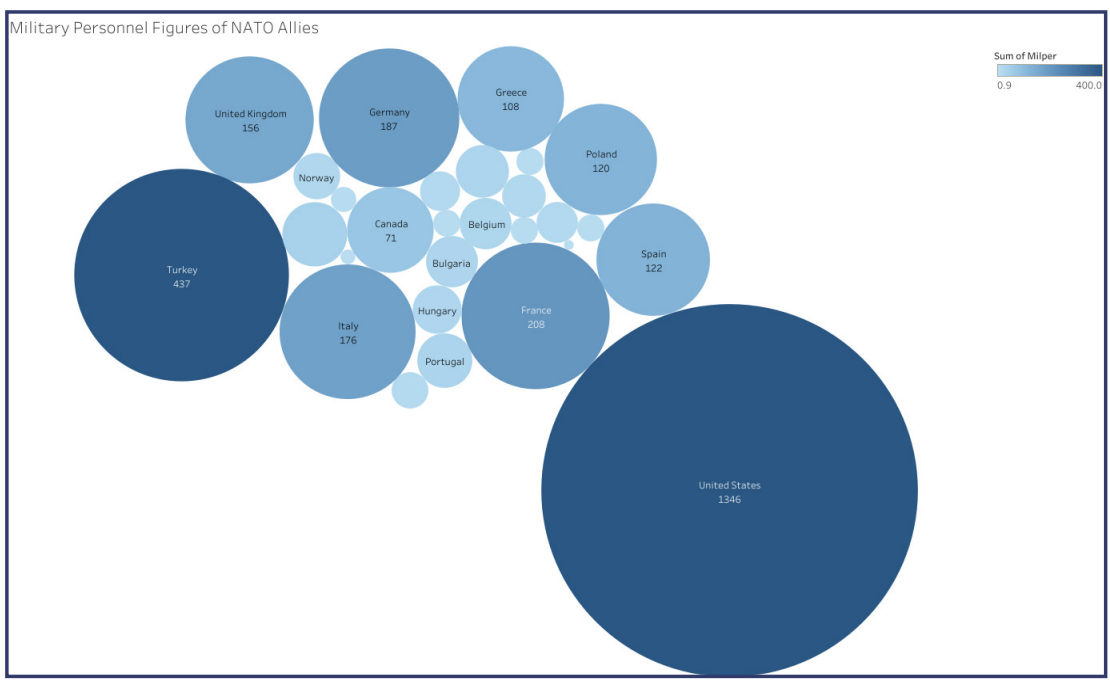

Figure 5. Military Personnel Figures of NATO Allies

To grasp what Turkey really means for NATO, one should look at military personnel figures as well. Turkey has the second-largest army of the Alliance, which has more manpower than the entire armed forces of 20 Allies. No NATO country can therefore compensate Turkey's withdrawal in terms of military staff

Consequently, NATO is a very crucial anchor for Turkey's security and well-being, and Turkey is an essential partner for the transatlantic Alliance, contributing to the security of the EU and the region surrounding the country as well, despite toxic political debates.

\section{Conclusion and Recommendations}

NATO-Turkey relations are experiencing a turbulent time due to several factors. Nevertheless, there is no substantial change or transformation in the technical/military dimension of the relations. Four reasons can explain the current situation.

- Strategic orientations cannot change overnight, even though some leaders strive for it.

- Conceptual/doctrinal and technical integration with NATO is so powerful to the extent that makes decoupling very challenging if not possible.

- $\quad$ Living in a fragile region, the cost of maintaining the territorial integrity of Turkey contained by Russia around borders without NATO is incomparably high.

- The identity/mindset of Turkish defence community (ideational aspect) is still Western-oriented. Yet, pro-Erdogan and Eurosianist groups are trying to consolidate their gains in post15 July Turkish army.

As depicted in this paper, despite strains, Turkey continues to be a member of NATO. The proponents of expelling Turkey from NATO have a slim chance, and it is too dangerous for both sides. Thus, there is no benefit in using this narrative. Instead, the problems and disputes should be discussed to find common ground and to set sail for new alternatives for cooperation. As the latest report, which is the outcome of reflection process points out, having robust militaries and the state of art warfighting capabilities are not sufficient in today's world. At the same time, the Alliance should also be politically coherent and robust. ${ }^{25}$ Resolving crisis with Ankara is not only about handling issues with Turkey, but it is also a manifestation of NATO's capacity to unravel problems and maintaining political unity even under the stormy weathers.

${ }^{25}$ Adapting NATO for 2030 and beyond, (2020). There are some brave proposals in the reflection group report addressing problems faced within the alliance. It is highly likely that some of these proposals will inform the next NATO Strategic Concept. 
To this end, our recommendations are as follows:

- In order to remain politically coherent;

- $\quad$ NATO should continue to use the de-escalation mechanism actively and effectively to prevent a conflict at sea and establish several mechanisms through which allies can discuss their problems (including agree to disagree on some issues).

- $\quad$ The NATO Secretary-General should task a group of experts (officially appointed experts if possible) from both sides to argue the current disputes and possible solutions which can be offered to allies, particularly to Greece and Turkey. The expert group can at least find the convergence/divergences among allies in a written report.

- Allies should show that they grasp Turkey's concerns and complaints, particularly in terms of YPG in Syria, and maritime delimitation issues in the Eastern Mediterranean.

- $\quad$ They should also manifest their concerns and illustrate the red lines of NATO once again and remind Ankara that NATO's security guarantees do not have to be taken for granted, which is essential for a Turkey located in a fragile region.

- $\quad$ Turkey should understand that disunity within the Alliance has a hefty price for both sides, especially in an environment in which Turkey is surrounded by Russia.

- $\quad$ Turkey should avoid inciting transatlantic peers by pursuing an overambitious policy and using a harsh discourse for domestic politics.

- It might be enlightening for Turkish foreign policy and defence planning practitioners to recall post-WWII circumstances which dictated Turkey certain geostrategic choices and which are still relevant.

Every ally has responsibilities to keep NATO up and running for ensuring its security considering the diminishing stability in the world and the fragility of NATO's South-eastern Flank. In any case, keeping strategic patience is more valuable for both sides than burning the bridges.

For grasping it, "You can just look at the map." 


\section{Between Rock and a Hard Place-French Vision of Radicalisation and an Alternative Perspective}

Onur Sultan ${ }^{1}$

\section{Introduction}

During his speech on the fight against separatism on October 2, 2020, the French President Emmanuel Macron said: "Islam is a religion which is in crisis today everywhere in the world" (L'Élysée, 2020). ${ }^{2}$ For support to his argument, the President made a simple comparison between the Muslim World today and the one 30 years ago, arguing the religion had been plagued everywhere by radical interpretations.

His statement caused a great disturbance and became the first link in a chain of events, as of today having the potential to unleash a "clash of civilizations." Two weeks after his speech, on October 16, Samuel Paty, a history teacher that had shown caricatures of Prophet Muhammad in a class on free speech was decapitated by Abdullakh Anzorov, an 18-year-old Chechen who lived in France since 2008. Macron during his visit to the site said: "One of our fellow citizens was assassinated today because he was teaching pupils about freedom of expression. Our compatriot was flagrantly attacked, was the victim of an Islamist terrorist attack" (Ojha, 2020). Then on October 29, three churchgoers were stabbed to death in Nice (BBC, 2020). And on November 2, a 20-year old Kujtim Fejzulai conducted a terrorist attack with a rifle and fake explosive belt in 6 different sites in Vienna, Austria, killing four while injuring at least 14 (Katkov \& Diaz, 2020).

Macron's initial speech and further sanctioning Paty's behavior of showing caricatures to the students as an extension of right to blaspheme as free speech has created a huge discussion in both within and outside France. Seen by those knowing internal dynamics of France as an effort to preclude rise of farright, his speech did neither succeed that goal nor did it satisfy others.

Several French parliamentarians were not content from the speech, stating Macron was stigmatizing Muslims by singling them out among other societal divisions (Euronews, 2020). In this regard:

Manon Aubry, a left-wing member of the European Parliament tweeted "Stigmatising Muslims, this is his only solution to try to hide his calamitous management of the health and social crisis." Alexis Corbière, a French MP from the left-wing party La France Insoumise, said Macron had only talked about radical Islam instead of focusing on an increasing gap between rich and poor and other societal divisions that, he said, influences "separatism" in poorer communities (Euronews, 2020).

His speech created rage across Muslim majority countries too. Responding to the events and rhetoric of free speech and Islamist terrorism that gained currency in France, Al-Azhar Observatory for Combatting Extremism posted on October 18 on its Facebook account: "Stigmatizing Islam with terrorism reflects ignorance of this noble religion, marks an attitude that lacks respect for other people's faith, expressly incites violence and reversion to the barbarism of the Middle Ages, and blatantly provokes the sentiments of around two billion Muslims." Then on October 21, Prof. Ahmed Al-Tayyeb the Grand Imam of Al-Azhar said: "Offending religions and denigrating their sacred symbols under the slogan of freedom of expression is a dysfunctional ambivalence and an explicit call for hatred" (Al-Azhar Observatory for Combating Extremism, 2020).

\footnotetext{
1 Onur Sultan is senior research fellow and project coordinator at Beyond the Horizon International Strategic Studies Group.

2 This is the relevant part of the speech by President Macron: "Islam is a religion which is in crisis today, everywhere in the world. We do not see it that in our country, it is a deep crisis which is linked to tensions between fundamentalisms, precisely religious and political projects which, we see in all regions of the world, lead to a very strong hardening, including in countries where Islam is the majority religion. Look at our friend, Tunisia, to cite just one example. 30 years ago the situation was radically different in the application of this religion, the way of living it and the tensions that we live in our society are present in this one which is undoubtedly one of the most educated, developed of the region. There is therefore a crisis of Islam, everywhere which is plagued by these radical forms, by these radical temptations and by an aspiration for a reinvented jihad, which is the destruction of the other. The project of a territorial caliphate against which we fought in the Levant, against which we are fighting in the Sahel, but everywhere, more or less insidious, the most radical forms. This crisis affects us by definition too."
} 
Not all reactions had the same neutral tone. Political leaders espousing political Islamist agenda, like Erdogan and Khan were quick to denigrate French President. In fact, President Erdogan went as far as to claim President Macron needed mental treatment (Sozcu, 2020). Far-right party leaders were some others that rubbed their hands for their good luck.

This paper does not seek to understand if Islam is in crisis or not. Nor does it seek to understand calculus behind President Macron's aims and intentions when making the statement. But it aims to test the validity of the claims, provide alternative reading to attain a balanced view and make policy recommendations.

\section{Rubber Hand Illusion}

Rubber hand illusion refers to an experiment where a person is asked to put his or her real hand beyond vision while keeping visual contact with a rubber hand. In the experiment, both the real and rubber hand are stimulated by strokes of a feather. After several minutes of synchronous stimulation of the rubber hand under visual contact and unseen real hand at the same time, the brain shifts its sensing functions on visual faculties. In other words, after a while the person starts feeling imaginary pain in case the rubber hand is brought close to a lighter fire or pricked with a pin. Interestingly, (s)he does not feel anything at all towards same stimulations, i.e. the prick or the approaching fire in the real hand.

This rubber hand metaphor can create a good understanding on French experience with radicalization and its conflating it to imperfection in Islam. President Macron is indeed right about the shift in Muslim societies in the last 30 years. But attributing the reason for the radicalization challenge in France to solely a crisis in Islam and stating this shift in Muslim world as its evidence is a claim to be tested.

A much-repeated dictum in statistics is that "correlation does not mean causal relationship." The geopolitical condition that has become a real test case for the mentioned geography has created observable negative sociological changes, exhibiting a certain correlation between hot spots on the globe and this religion. But deciding on if it is Islam that causes this deterioration needs more scrutiny.

\section{Third Wave of Civil Wars}

Barbara F. Walter, in her article The New New Civil Wars clusters civil wars in three distinct waves since the end of World War II: a first wave from 1951 to the end of the Cold War, a second wave from 1992 to 2001, and a third wave from US invasion of Iraq in 2003 up till now (2017). Although the last thirty years corresponds to the $2^{\text {nd }}$ and $3^{\text {rd }}$ waves, a closer look at the third wave shows it is the exact picture Macron refers to.

\begin{tabular}{|l|c|c|c|c|}
\hline Location & $\begin{array}{l}\text { Episode } \\
\text { Start Date }\end{array}$ & $\begin{array}{l}\text { Muslim Majority } \\
\text { Country }\end{array}$ & $\begin{array}{l}\text { Muslim } \\
\text { Population \% }\end{array}$ & $\begin{array}{l}\text { Islamist } \\
\text { Rebellion }\end{array}$ \\
\hline Iraq & 2004 & Yes & 99 & Yes \\
\hline Chad & 2005 & Yes & 56 & No \\
\hline Sri Lanka & 2005 & No & 9 & No \\
\hline Somalia & 2006 & Yes & 99 & Yes \\
\hline Pakistan & 2007 & Yes & 96 & No \\
\hline Rwanda & 2009 & No & 2 & Yes \\
\hline $\begin{array}{l}\text { Yemen } \\
\text { (N.Yemen) }\end{array}$ & 2009 & Yes & 99 & Yes \\
\hline Syria & 2011 & Yes & 93 & No \\
\hline Libya & 2011 & Yes & 97 & Yes \\
\hline Nigeria & 2011 & Parity & 50 & No \\
\hline South Sudan & 2011 & No & 6 & \\
\hline
\end{tabular}




\begin{tabular}{|l|l|l|l|l|}
\hline Location & $\begin{array}{l}\text { Episode } \\
\text { Start Date }\end{array}$ & $\begin{array}{l}\text { Muslim Majority } \\
\text { Country }\end{array}$ & $\begin{array}{l}\text { Muslim } \\
\text { Population \% }\end{array}$ & $\begin{array}{l}\text { Islamist } \\
\text { Rebellion }\end{array}$ \\
\hline CAR & 2012 & No & 15 & No \\
\hline Mali & 2012 & Yes & 90 & Yes \\
\hline DR Congo & 2012 & No & 1.4 & No \\
\hline Israel/Palestine & 2014 & Parity & 49 & Yes \\
\hline Ukraine & 2014 & No & .9 & No \\
\hline
\end{tabular}

Table 1. Countries Afflicted by the Third Wave of Civil Wars (Walter, 2017)

Drawing attention to the significant rise of civil wars since 2003, Walter differentiates this third wave of civil wars from the previous ones through three defining features:

- The majority of them are situated in the Muslim-majority countries (65\%),

- The vast majority of the rebel-groups in fighting hold radical Islamist goals, and

- Most of such groups pursue transnational aims rather than national ones.

She further argues, this new wave of civil wars tends to last a long time, involve multiple fighting factions, feature significant outside involvement and reflect deep societal divisions.

Walter in fact verifies Macron's claims that the landscape in Muslim majority countries in the last 30 years, but especially in the 20 years has changed significantly. But the reasons she gives for this change is a bit different. She says: "Existing macro-level studies help illuminate why so many civil wars have broken out in Muslim majority countries. Chad, Iraq, Libya, Pakistan, Somalia, Syria, Nigeria, Mali, CAR and Yemen are all countries where GDP per capita is low, unemployment is high, and governments are repressive, corrupt and unconcerned with the rule of law." All in all, she attributes the reasons for the unrest in these countries to poverty, repression, significant outside involvement and deep societal divisions.

\section{Role of Radical Ideologies}

But still, we need to be able to explain the reason why radical interpretations of Islam are espoused by the fighting groups in so many civil wars. Basing her calculations on Stanford CISAC database, Walter estimates Salafi-jihadist groups make up some 35\% of the major militant groups in Iraq, 50\% of such groups in Somalia, and 70\% of them in Syria (Walter, The New New Civil Wars, 2017). Why has this ideology become so much prevalent in the civil wars we observe today?

Walter explains this in another article with the name The Extremist's Advantage in Civil Wars. She argues espousing an extreme ideology like Salafi-jihadism offers rebel entrepreneurs "significant organizational advantages over more moderate groups." Accordingly, irrespective of whether they believe in underlying core tenets or not, embracing extremist ideologies help leaders overcome collective action problem, using the ideology as vehicle or tool to raise units of men ready to accept the cost of fighting and death. As opposed to secular groups that offer money, security and material rewards, Salafi-jihadist organizations bring the cost of death to zero, offering heaven in an afterlife instead of material offers. The second advantage is that extremist ideologies help overcome principalagent problem. They show utility in raising committed fighters that require less control and help curb side-switching, betrayal or poor performance. More devoted fighters show more audacity in the conflict. The third advantage is that they serve as an assurance that once in power, the leaders will resist corruption. Walter says:" This is especially important in countries with few institutional constraints on government elites and a history of exploitation." So, an extremist ideology that requires personal sacrifice of the leaders function as motivator for lower-level fighters to make more efforts in the same direction. This last advantage has two aspects in reality, one that has influence on ingroups and another on average citizens taking position vis-à-vis such groups in their vicinity. The 
belief that leaders of extremist groups will not yield to corruption once in power is one of the two main factors that earn them average citizen support, the other being belief in high chances that respective group will win the war. So, as can be understood above, there is a mathematics behind use of certain extremist ideologies and how support behind those ideologies from in- and out-groups form (Walter, The Extremist's Advantage in Civil Wars, 2017).

\section{Why Do Radical Ideologies Find Audience in Europe?}

Many reasons can be cited, varying from case to case and often specific to the context. But, an important factor to be cited is the identity crisis or an effort to find his / her place in the society. Initially taking flight after 9/11 attacks, change of attitude towards Muslims and discourse conflating Islam to terror and securitization of the Muslim identity has been a reason for identity crisis, alienation and polarization (Hafez, 2015). This polarization has functioned as both a reason and a result of radicalization. So it is arguable that, inter alia an important cause of polarization is prevalent negative stereotypes about Islam and Muslims. This has further caused in a chain reaction lack of integration and thus low-level representation of the Muslims in public space, public discourse and policies. A Pew Survey conducted in Spring 2016 in 15 European countries shows especially in southern and eastern Europe, i.e. Hungary, Italy, Poland and Greece, rate of citizens holding negative views towards Muslims can be as high as 72 percent (Pew Research Center, 2016).

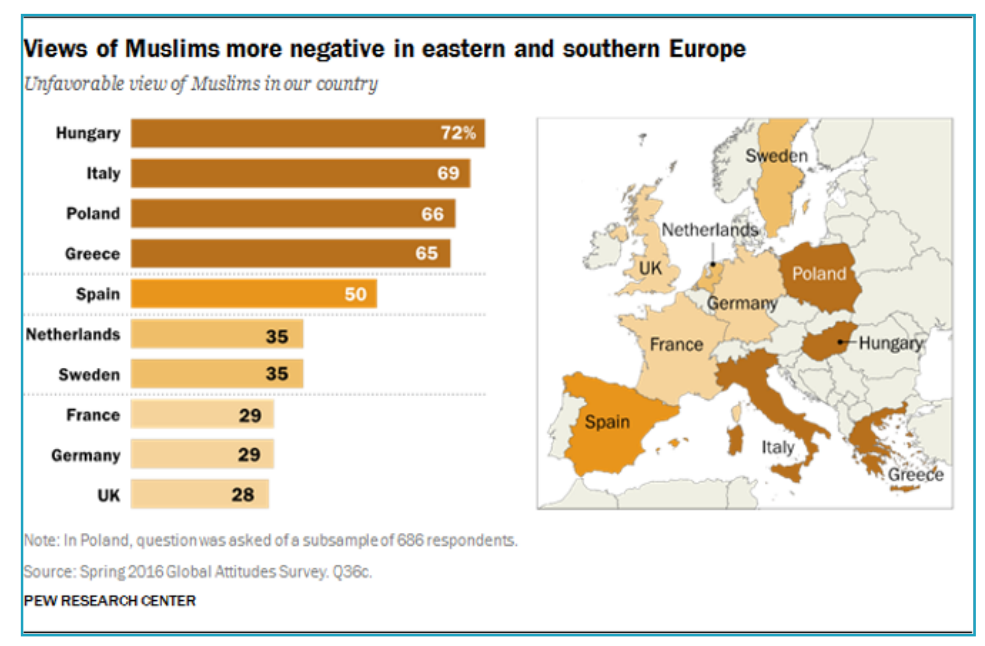

Figure 1. Pew Survey on View Towards Muslims.

Along the same lines, in their article on challenges to create counter-narratives, Speckhard and Shajkovci argue: "The main recruiting pool for groups like ISIS are Muslim converts and secondgeneration Muslim immigrant communities who have not found the promises of the EU to match their daily realities. In formal and informal interviews with hundreds of EU citizens to date, ICSVE researchers have found sentiments of Islamophobia, discrimination, and marginalization to be widely prevalent in their daily lives and experiences (Speckhard \& Shajkovci, 2018)."

In fact, the number of people that join such groups directly for ideological reasons is low. In his piece where he presents the case of two ISIL terrorists, Mehdi Hassan says before their journey to Syria, the two books they bought from Amazon were "Islam for Dummies" and "Koran for Dummies." He further continues:

In 2008, a classified briefing note on radicalisation prepared by MI5's behavioural science unit was leaked to the Guardian. It revealed that, "far from being religious zealots, a large number of those involved in terrorism do not practice their faith regularly. Many lack religious literacy and could ... be regarded as religious novices." The analysts concluded that "a well-established religious identity actually protects against violent radicalisation", thenewspaper said(Hassan, 2014). 
Redouan Safdi, an imam that is involved in the deradicalization of FTFs alongside home-grown terrorists and radicals in a Belgian prison designed for terrorist offenders says about his encounters with radicals and returnees: "They would usually start talking about that they have love for Islam, they want to live in an Islamic state, they want to live somewhere where shariah is implemented. When you go deeper with them in the conversation, when conversations are more meaningful, I would hardly hear them speak about Islamic state or the implementation of shariah. All I would hear is the injustices they have experienced in the past: racism, discrimination, poverty, lack of opportunity. [...] The majority of them are very young people. Many of them haven't even reached the age of 18. They are frustrated, alienated socially. Young people who are in search of identity, a meaning in life. Young people that did not feel at home in their own countries where they were born, who felt they were not appreciated" (Safdi, 2020).

If we accept travel to a conflict zones like Syria and Iraq to join various jihadi groups as a positive answer to the call from radical extremist groups, an interview conducted by the author in February 2019 reveals the role of ideology. The interviewee, a social worker in Brussels, said: "In each case we see a person making the travel to Syria and Iraq, if we scratch the surface [if we delve deeper into the issue], we find a familial, social or economic problem."

President Macron attests to this diagnosis in his October speech where he says:

We ourselves have built our own separatism in our neighborhoods, creating ghettos in the beginning with the best intentions in the world. But we let it happen, that is to say that we had a policy, we have sometimes called it a settlement policy, but we have built a concentration of misery and hardship, and we know that very well. We have concentrated populations often according to their origins and social backgrounds. We have concentrated the educational and economic difficulties in certain districts of the Republic (L'Élysée, 2020).

\section{France and Radicalisation}

France is a country with some 5 million Muslims corresponding to roughly $9 \%$ of the population. Initially coming to take menial jobs like construction and car manufacturing in the 1970s, with the new generations Muslims started to get better education and better positions. The more they came to the public view with their lifestyles and world views, the more far right seized upon it as a threat to the French identity. The secular identity of the state called "laïcité" and its use to limit religious signs in most cases influencing Muslims has been a reason for strained relations between Muslims and the state (Ganley, 2020). France has been a target of jihadi attacks since 1994. But, the joining of a great number of French nationals to the Islamic state, the Charlie Hebdo shootings and Paris attacks has carved the importance of the issue of terror and radicalization into the mind of

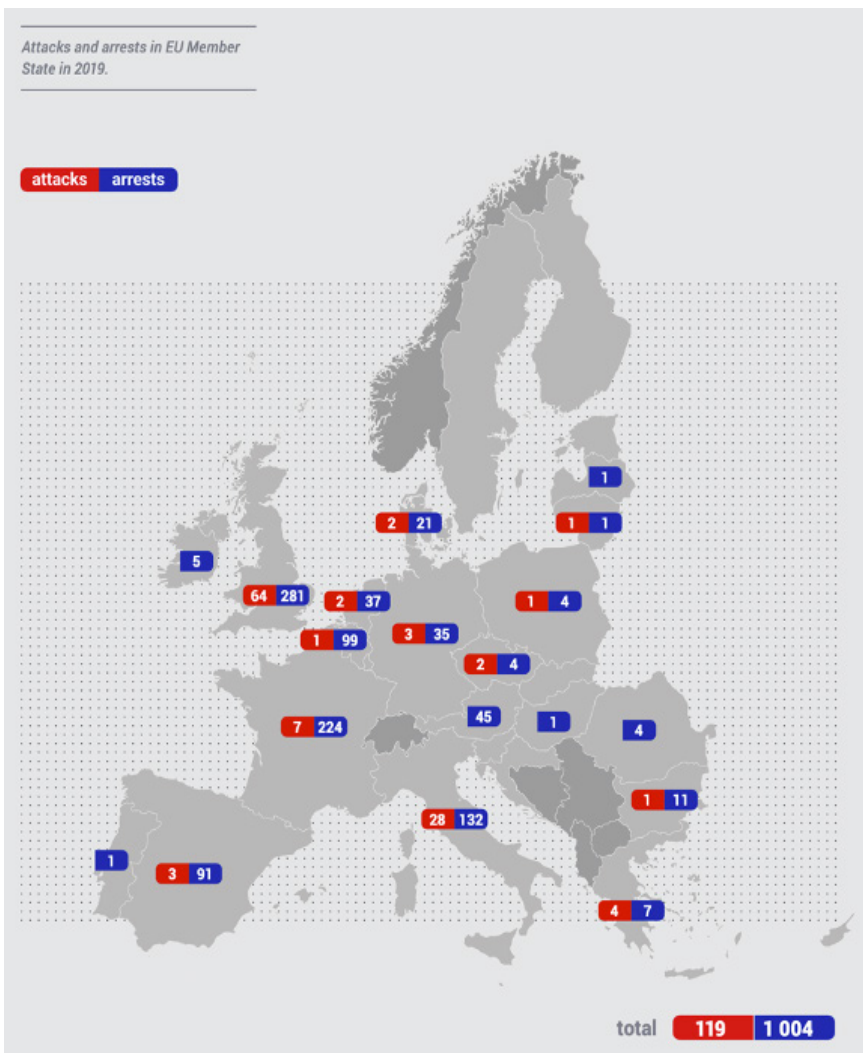

Figure 2. Attacks and arrests in EU Member State in 2019 (TE-SAT 2020). the general public. To lay bare the importance of the former, 1910 French nationals have been reported
to travel to Syria and Iraq to join various jihadi groups or have been stopped on the way. This figure 
corresponds to nearly 40 percent of the total 5000 from the EU (Barrett, 2017). Unfortunately, the issue still maintains its importance. According to TE-SAT European Union Terrorism Situation and Trend Report 2020, in 2019 France witnessed 7 terrorist attacks and 224 terror-related arrests, responding to the greatest number across the EU in both categories (EUROPOL, 2020).

Despite the greatness of this problem of radicalization, it is not possible to say the country has developed required reflexes to counter this threat. In the past years, France has been mentioned more about its failures than its successes about putting up programs of disengagement, deradicalization, rehabilitation and reintegration (Jacinto, 2017). In the country, few non-profit organizations and private initiatives offer competent assistance to the radicalized individuals and help solution of the problem (Schwarzenbach, 2019). Yet, the number of French nationals believed by security forces to pose threat increase within "fiché S" or S file. Reuters reports there are about 26,000 people in the file about 10.000 of which are believed to be religious extremists (Salaün, 2020). As the number increase so does the inability of the French state institutions to track and deal with so many people.

\section{Policy Recommendations}

The statements by the President Macron has became a tool for manipulation by political Islamists, far right parties and Salafi-jihadist organizations alike. We have been seeing attacks across Europe since his speech on September 2, which such terror groups use to increase their brand value and visibility. France is at crossroads to adjust its position vis-à-vis its 5 million Muslim citizens in application of "laïcité" to find the delicate balance between countering radicalization and mending its social contract. Here are several considerations and policy recommendations in this regard:

Fighting radicalization towards all types of violence (jihadi, extreme right, anti-Semitist, etc.), polarization and hate speech should be the norm. But conflating radicals and extremist groups -who feed on manipulating certain religious texts- as the representatives of a certain religion when doing so, will not help anything else than providing bullet to the propaganda machine of the political Islamists, far right parties and such marginal groups. This will further erode legitimacy basis of the respective state, estranging citizens towards the itself.

France has every right and obligation to take necessary measures to stem radicalization leading to violence on French soil. But before launch of any initiative, there is one overarching pre-condition that should be satisfied. The state agents and institutions have to be perceived by all citizens as acting in accordance with the standards of a just procedure which implicates neutral and transparent decision making, and fair and respectful treatment. This way the French state will gain the trust of its citizens and its legitimacy in their eyes. This will help "minimise structural and cultural inequalities and empower marginalised individual or groups, and thus address macro-level grievances assessed to have a role in the prevention of terrorism and radicalisation" (Schwarzenbach, 2019, p. 105).

The latest support of Macron and other political figures to the caricatures as "right to blaspheme" under free speech functions as a divisive force in France and through the discussion created, in the globe. Forming a central tenet of liberalism, harm principle says individuals' freedoms terminate at a point where it causes harm to the others. Although there is no agreed definition, UN defines hate speech as "any kind of communication in speech, writing or behaviour, that attacks or uses pejorative or discriminatory language with reference to a person or a group on the basis of who they are, in other words, based on their religion, ethnicity, nationality, race, colour, descent, gender or other identity factor." The events we have observed in each time the caricatures have been published (in Denmark and France) pushes us to conclude on their provocative nature. Based on harm principle, definition of hate speech and the life loss each time they are published, they should not qualify for being subject of free speech. France, with all its troubles about radicalization, should avoid political maneuvers that will further polarize French society. Instead of considering the phenomenon as representation of a certain religious ideology, the roots of radicalization should be sought in social crisis. Instead of stigmatizing Muslims and deepening the divide, France should seek ways to renew the social contract with this community. 
Although sharing huge commonalities, Islam and Christianity have different historical evolutionary paths, varying mechanics in terms of openness to reform and differences in positioning God, prophets and art. Labelling radical ideologies espoused by an extremely marginal group not having any right or power of representing Islam as the latter's plague, and packaging measures to counter radicalization as an effort to reform Islam naturally enrages Muslims and opens a vast space for abovementioned groups that feed on divisions and contentious issues. Especially for violent extremist groups, the developments opened up an opportunity to increase the volume of their propaganda by words and deeds. So, before deciding on issues that will have repercussions on the Muslims' lives in France, the government should form informed decisions requiring active involvement of moderate voices, community representatives and religious authorities. Benchmarking Christianity to make decisions on Islam might not always be the right way of conduct.

The external financing of persons, networks and organizations that conduct activities to result in estrangement and radicalization of French / European nationals (be it migrant descendent or not) should be cut. Individuals, networks and structures that conduct violent acts upon orders from external states should be closely followed and penalized. For this, France and the other MS should have an open eye and they should develop capacity to replace such structures offered/funded by foreign states.

Politicians and people with certain influence diameter should avoid raising rhetoric that can provoke protests and reactions from different faith groups. At a time when the globe is struggling to protect itself from the coronavirus, there is no need to create another artificial crisis that will further cause division and polarization. Unity in solidarity and respect to the others should be valued and extended. 


\section{Bibliography}

Barrett, R. (2017). Beyond the Caliphate: Foreign Fighters and the Threat of Returnees. The Soufan Center.

BBC. (2020, October 31). Nice attack: Grief and anger in France after church stabbings. From BBC News: https://www.bbc.com/news/world-europe-54745251

Euronews. (2020, October 2). France: Emmanuel Macron presents plan against 'Islamic seperatism'. Retrieved October, 2020 from https://www.euronews.com/2020/10/02/france-emmanuel-macron-presents-plan-against-islamic-separatism

EUROPOL. (2020). the European Union (EU) Terrorism Situation and Trend Report (TE-SAT) 2020. European Union Agency for Law Enforcement Cooperation.

France24. (2020, October 21). We will not give up cartoons: Macron in homage to murdered teacher. Retrieved November, 2020 from France24: https://www.france24.com/en/live-news/20201021-we-will-not-giveup-cartoons-macron-in-homage-to-murdered-teacher

Ganley, E. (2020, November 1). French Muslims, stigmatized by attacks, feel under pressure. Retrieved November, 2020 from Associated Press: https://apnews.com/article/paris-france-emmanuel-macron-islam-europe-ea5e15bb651bbe443b27bc19948cae6b

Hafez, M. (2015). The radicalization puzzle: a theoretical synthesis of empirical approaches to homegrown extremism. Studies in Conflict and Terrorism, 38, 958-975.

Hassan, M. (2014, August 21). What the Jihadists Who Bought ‘Islam For Dummies' on Amazon Tell Us About Radicalisation. From HuffPost: https://www.huffingtonpost.co.uk/mehdi-hasan/jihadist-radicalisation-islam-for-dummies_b_5697160.html

Jacinto, L. (2017, August 01). France's 'deradicalisation gravy train' runs out of steam. Retrieved February, 2020 from France24: https://www.france24.com/en/20170801-france-jihad-deradicalisation-centre-closes-policy

Katkov, M., \& Diaz, J. (2020, November 3). ISIS Claims Credit in Vienna, Austria ‘Terror Attack'. Retrieved November, 2020 from NPR: https://www.npr.org/2020/11/03/930721562/at-least-4-killed-by-gunman-in-vienna-austria-in-terror-attack?t=1604578448415\&t=1604670620585

L'Élysée. (2020, October 2). La République en actes : discours du Président de la République sur le thème de la lutte contre les séparatismes. Retrieved October, 2020 from https://www.elysee.fr/emmanuel-macron/2020/10/02/la-republique-en-actes-discours-du-president-de-la-republique-sur-le-theme-de-la-lutte-contre-les-separatismes

Ojha, S. (2020, October 17). President Macron calls teacher's beheading in France "Islamist terrorist attack". Retrieved 2020, October from NewsBytes: https://www.newsbytesapp.com/timeline/world/67524/318727/ teacher-beheaded-in-paris-for-showing-prophet-s-caricatures

Pew Research Center. (2016, July 11). Views of Muslims more negative in eastern and southern Europe. Retrieved February, 2019 from Pew Research Center: https://www.pewresearch.org/global/2016/07/11/europeans-fear-wave-of-refugees-will-mean-more-terrorism-fewer-jobs/ga_2016-07-11_national_identity-00-01/

Reuters. (2020, September 15). France's Macron: I won't condemn cartoons of Prophet Mohammad. Retrieved November, 2020 from Reuters: https://www.reuters.com/article/france-charliehebdo-trial-cartoons-macro-idUSKBN25S672

Salaün, T. (2020, October 17). French police face worst nightmare: an attacker they never saw coming. Retrieved November, 2020 from Reuters: https://www.reuters.com/article/us-france-security-attacker-idUSKBN2720NJ

Schwarzenbach, A. (2019). Counter-Radicalisation Strategies: An Analysis of German and French Approaches and Implementations. In B. Akhgar, D. Wells, \& J. M. Blanco, Investigating Radicalization Trends: Case Studies in Europe and Asia (pp. 101-122). Springer.

Sozcu. (2020, October 24). Cumhurba kanı Erdo an'dan Macron'a sert sözler: Tedaviye ihtiyacı var. Retrieved November, 2020 from Sozcu: https://www.sozcu.com.tr/2020/gundem/cumhurbaskani-erdogandan-macrona-sert-sozler-tedaviye-ihtiyaci-var-6096221/

Speckhard, A., \& Shajkovci, A. (2018, November 27). Challenges in Creating, Deploying Counter- Narratives to Deter Would-be Terrorists. From Homeland Security Today.us: https://www.hstoday.us/subject-matter-areas/ terrorism-study/perspective-challenges-in-creating-deploying-counter-narratives-to-deter-would-be-terrorists/

Walter, B. F. (2017). The New New Civil Wars. Annual Review of Political Science, 20, 469-486.

Walter, B. F. (2017). The Extremist's Advantage in Civil Wars. International Security, 42(2), 7-39. 


\section{Book Review: The New Despotism, John Keane (2020)}

Ibrahim Genc ${ }^{1}$

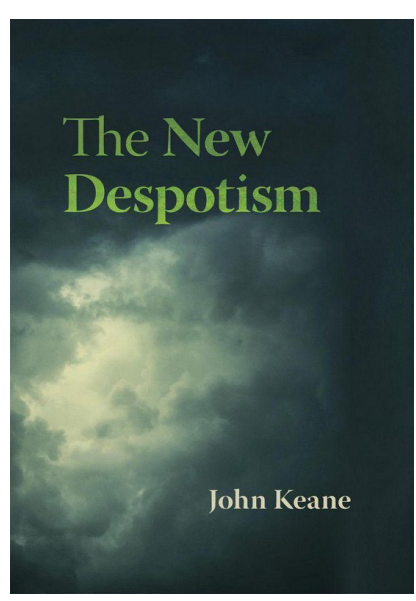

As someone who has been following John Keane for a while, it would be accurate to say that The New Despotism (2020) is the accumulation of his ideas and writings in the last four years or so. To briefly describe the book, it is a book that examines how countries like Hungary and China survive and thrive in the previous few decades despite their efforts to undermine democracy. For Keane, such regimes outperform their predecessor thanks to their ability to learn and adapt.

Written in the style of Niccolò Machiavelli's tough-minded classic The Prince (1532), he offers us a different lens to look through when judging the puzzling political developments of the present world. He revisits the old-fashioned term despotism and offers us his fresh take on it. He argues that, albeit these new emerging regimes may resemble the past regimes, they have unique qualities to survive and thrive. Perhaps, their most distinctive quality is their ability to learn and adapt or, as Keane puts it, "They strive to become learning despotisms."

"We could say that," writes Keane, "Today's despotism is a new type pseudo-democratic government led by rulers skilled in the arts of manipulating and meddling with people's lives, marshalling their support, and winning their conformity. Voluntary servitude is their thing." The latter sentence indicates that the new despotisms are capable of winning the consent of their subjects. The question then becomes, "How these regimes win the support of the people?" To answer this question, Keane offers vital attributes of the new despotisms. To name them, establishing successful patron-client connections, deploying the rhetoric of the people, smart censorship of the media, the use of carefully targeted violence, and lastly, their ability to make the citizenry believe that they live in a democracy.

Through patron-client connections, these regimes manage to keep everyone have a vested interest in the government. As he puts it delicately, "everyone in the system, from top to bottom, is involved in daily navigations through the reefs and islands and archipelagos of connections, favours, setbacks, failures, and successes". Though these connections are incredibly corrupt, if one wishes to get his/her job done, it is almost impossible to avoid becoming part of these patron-client networks. Furthermore, Keane points out the importance of the middle class in these countries. Depicting this importance, "It also functionally," Keane posits, "depends on loyal middle class who are prepared to trade some liberties for comfortable peace and quiet".

As Keane proposes a new term, the new despotisms, consequently, he is critical of the old-fashioned use of despotism and other terms to describe these new regimes. "It is wrong," he contends, "to describe the new despotisms as autocracies or as systems of authoritarianism, the supposed opposite of liberal democracy". "These despotisms," he adds, "cannot be understood by adding a qualifying prefix or suffix to the word democracy".

The author successfully reveals that despite many differences, the new despotisms of our times have a similar pattern in governing their subjects. They try to make their subjects believe that their living standards are better than past and improving. To convince their citizens that the present is better than the past, these regimes engage in a few practices of creating a feeling that there are more opportunities for the citizens at their disposal than before. For instance, "the number of shopping malls jumped nearly eightfold during the first two decades of rule by Erdogan." Similarly, in Kazakhstan, the government built a brand-new capital as a representation of the state's power and ability to "reward, rather than

1 Ibrahim Genc is a PhD candidate in the school of government and international relations at Griffith University. He is also a research editor at Democratic Decay and Renewal (Dem-Dec). 
to rob".

Apart from pointing out the new despotisms' standard features and strengths, Keane also examines these regimes' weaknesses. "Frailty," Keane writes, "is a curse of despotism. Cognizant of the risks, despots always make "they believe in the people, and that their sole purpose as rulers is to serve the people, whose support they enjoy".

Moreover, to appear healthy, they often have a team tasked to create a perfect picture of their personality. When this perfectly carved out image of a strong leader starts cracking, despots become susceptible to threats such as economic crisis. Additionally, sitting atop patron-client networks, the oligarchs have the power to keep or remove the sitting president/ prime minister in office when there is an apparent disturbance amongst the citizenry. For Keane, under these circumstances, the oligarchs are always willing to preserve the system than the ruler. Therefore, it is logical to state that this is a great weakness for despots. For that, rulers of these new despotisms always must find a way to keep tabs on the oligarchs while protecting his/her power. While when this balance is protected, this relationship proves to be useful. However, when this unspoken agreement fails, the oligarchs might start scattering, thus leaving the leader vulnerable.

As stated above, the author presents a new term, 'The New Despotisms.' Though there seem to be many references to China, the book also offers rich examples from other countries like Russia, Turkey, and Hungary. As Keane argues that the terms such as autocracy and authoritarianism fail to grasp the complexity of these new regimes, "the word despotism discourages us from thinking in black-andwhite terms". Regardless of the discussion that which terms would better explain these countries, it is clear that Keane's claims will prompt more conversation and force us to think beyond the conventions.

For those who want to understand this book better, reading Keane's book When Trees Fall Monkeys Scatter will be of great help. Lastly, for those who seek to research this area, Keane notes that "A full understanding of the resources of their resilience would require an in-depth grasp of their particular histories". In addition to forcing us to think beyond traditional lines, this book will surely inspire many future researches into the nature of the new despotisms. 
(1.)@Beyond the Horizon

(7) @BehorizonOrg

@BehorizonOrg

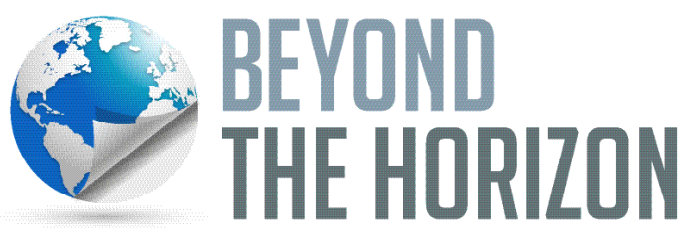

INFLUENCING AND PROMOTING GLOBAL. PEACE AND SECURITY 